\title{
Physicochemical quality of brown soybean preserve in function of maceration time and ascorbic acid
}

\author{
Adriana Luiza Wain TASSI ${ }^{1}$, Juliana Aparecida Correia BENTO ${ }^{1}$ (D), Márcio CALIARI ${ }^{1 \star}$, Vera Sônia Nunes da SILVA², \\ Maria Teresa Bertoldo PACHECO ${ }^{2}$, Rosângela VERA ${ }^{1}$, Manoel Soares SOARES JÚNIOR ${ }^{1}$
}

\begin{abstract}
The aim of the present study was to evaluate the physical and chemical quality of the brown soybean preserve in function of the ascorbic acid concentration and the maceration time, and also to evaluate the chemical composition, microbiological hazard, and acceptability of the best preserve, in addition verify its technological, nutritional, functional and sensory viability. The hardness of the grain ranged between 8.6 and $23 \mathrm{~N}$ and was significantly affected by the maceration time. The ascorbic acid concentration influenced antioxidant activity (ranged between 4.3 and $183.8 \mathrm{mg}^{100 \mathrm{~g}^{-1}}$ ) and total phenolic compounds (ranged between 176.4 and $\left.466.2 \mathrm{mg} 100 \mathrm{~g}^{-1}\right)$. The best brown soybean preserve was obtained with a maceration time of $23 \mathrm{~min}$ and an

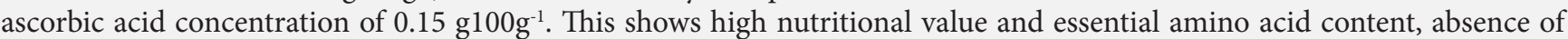
trypsin inhibitor and microbiological risk, and also sensory acceptance. Therefore, the brown soybean preserve is viable, and its consumption is recommended.
\end{abstract}

Keywords: texture; colour; antioxidant capacity; proximal composition; amino acids profile.

Practical Application: The food industries have been looking for food products, which provide nutritional function for consumers, like antioxidant activity. The brown soybean preserve is an interesting product, with a similar appearance to beans, which present antioxidant activity and phenolic compounds. Besides that, brown soybean preserve it's a way to improve the acceptance of the soybean by the Brasiliams consumers.

\section{Introduction}

The soybean (Glycine max (L.) Merrill), a leguminous crop originating in Asia and cultivated in almost all regions of the planet, is a grain of great interest in the worldwide economy and plays an important role in human nutrition because of its nutritional and functional properties (Kim et al., 2014).

Although Brazil is the world's second-largest soybean producer, consumption is low among Brazilians. Researchers have expended great efforts and investments in obtaining cultivars with more acceptable sensory characteristics in order to introduce this leguminous plant into the Brazilian diet. Moreover, the development of soybean cultivars for human food (with free or low-lipoxygenase content, which improves the flavor), health benefits divulgation, and consumer interest has increased. The brown tegument soybean is an alternative for increasing consumption in Brazil, relyingon its similarity to Pinto beans, a typical Brazilian cuisine (Ciabotti et al., 2016).

Due to its nutritional superiority among beans, the brown soybean is an excellent option for governmental programs against malnutrition, as it can be introduced into school meals or basic-needs grocery packages. In this context, develop physical and chemical quality of the brown soybean preserve in function of the ascorbic acid concentration and the maceration time of a brown soybean preserve might create new consumption opportunities because the product's appearance is similar to be

an broth, a dish that plays an integral part in the Brazilian diet. This similarity to a familiar food could help avoid consumer resistance, besides preserving the product for a longer period (Mozzoni et al., 2009).

Hydration time of the grains is important point for the production of canned soybeans. The hydration or maceration is widely used in the processing of soybean products because this grain usually contains anti-nutritional compounds and substances that give odor and unpleasant taste, which can be minimized or excluded through this operation (Khattab \& Arntfield, 2009). Maceration reduces phytate levels in soybeans; however if the grains remain for a long time in the hydration process, it can cause significant losses of soluble protein and total solids because of unabsorbed grains (Bayram et al., 2004a).

The common use of additives in canned soybean production aims to keep the colour and improve sensory characteristics. However, additives can also be used in order to maintain or increase the antioxidant activity of the food, in which ascorbic acid has been used in food conservation (Sogvar et al., 2016).

The aim of the present study was to evaluate the physical and chemical quality of the brown soybean preserve in function of the ascorbic acid concentration and the maceration time, and also to evaluate the chemical composition, microbiological 
hazard, and acceptability of the best preserve, in addition verify its technological, nutritional, functional and sensory viability.

\section{Materials and methods}

\subsection{Raw $m$ aterials}

The brown soybean (BRM line 04-4382-4) used in the preserve was cultivated in a conventional system at the Federal University of Goias - Samambaia Campus, Goiania - GO, Brazil, season 2013/2014. The material was donated by the Empresa de Pesquisa Agropecuária de Minas Gerais (EPAMIG). After cultivation, the grains were harvested and selected manually. Ascorbic acid P.A $\left(\right.$ Sigma $\left.^{\circledR}\right)$, fresh garlic and virgin olive oil $\left(\mathrm{Galo}^{\circledR}\right)$ were purchased in local shops in Goiania.

\subsection{Brown soybean preserve processing}

Response surface and the Central Composite Rotational Design, with four factorial points, four axial, and three central points, totaling eleven experiments, was utilized (Box et al., 2005). The independent variables were maceration time $(0,13.6,50,85.4$ and $100 \mathrm{~min})$ and concentration of ascorbic acid solution in the brine (relative to the mass of the grains)

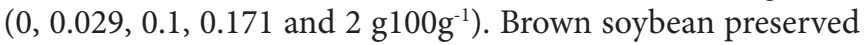
processing is presented in the following diagram (Figure 1).

Selected grains were bleached in boiling water at a ratio of 1:5 for $5 \mathrm{~min}$, immediately drained and washed in cold water for approximately $1 \mathrm{~min}$, then macerated in mineral water for different times, which had been defined in the experiment. After the maceration stage, the preserve was processed and packed in a transparent glass recipient $(30 \mathrm{~mL})$, containing $1 \mathrm{~g}$ of garlic (chopped and fried in virgin olive oil) and a covering liquid (approximately $15 \mathrm{~mL}$ ) composed of mineral water and

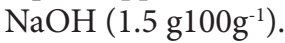

Then, an exhaustion was performed for $10 \mathrm{~min}$. After the exhaustion, ascorbic acid was added in different concentrations, which had been defined in the experiment, and the recipient was immediately sealed and taken to the pre-heated autoclave. The heat treatment was performed for $15 \mathrm{~min}$ at $120^{\circ} \mathrm{C}$. Immediately after the gradual addition of cold water into the open autoclave, cooling was performed. The final products were stored at a refrigeration temperature of $5{ }^{\circ} \mathrm{C}$ until the analyses. The responses analyzed were instrumental colour parameters (luminosity, chroma $\mathrm{a}^{*}$, and chroma $\mathrm{b}^{*}$ ), instrumental hardness, antioxidant activity $\left(\mathrm{DPPH}^{\star}\right)$ and total phenolic compounds. Regression models were validated by a test with three repetitions of the preserve with higher desirability (optimized).

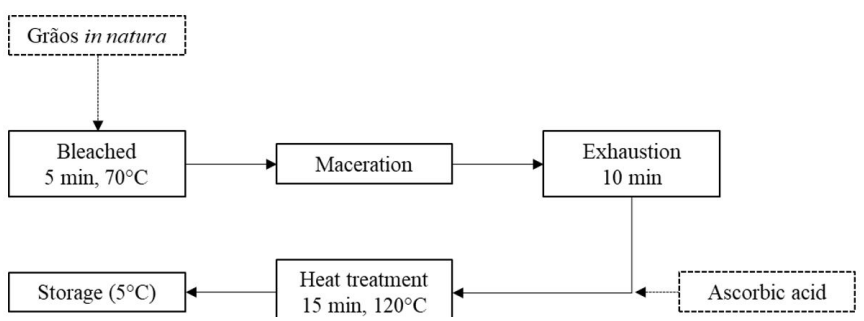

Figure 1. Diagram of the brown soybean preserved processing.

\subsection{Instrumental hardness}

Analyses were performed on six whole grains per experiment, using a texturometer (TA, XT2, Halesmere, England) with an aluminum cylindrical probe that was $20 \mathrm{~mm}$ in diameter $\left(\mathrm{P}_{20}\right)$. Pre-test, test and post-test speedswere set at $2 \mathrm{mms}^{-1}$, with a height of $15 \mathrm{~mm}$.

\subsection{Total phenolic compounds}

Extracts for quantification of total phenolic compounds (TPC) and antioxidant activity were obtained according to the method reported by Hung et al. (2009). Quantification of TPC was performed according to the method proposed by Singleton et al. (1999). The absorbance was measured at $760 \mathrm{~nm}$, using a spectrophotometer (BEL Photonics, S 2000 UV, Osasco, Brazil). The results were expressed as $\mathrm{mg}$ gallic acid equivalent per gram of sample $\left(\mathrm{mgGAEg}^{-1}\right)$ on a dry basis. The analyses were performed in triplicate.

\subsection{Antioxidant activity}

Antioxidant activity was determined by the 2.2-diphenyl-1-picryl-hidrazil (DPPH) radical-scavenging method, according to Thaipong et al. (2006). The absorbance was measured at $517 \mathrm{~nm}$, using a spectrophotometer (BEL photonics, S 2000 UV, Osasco, Brazil). Total antioxidant activity was expressed as $\mathrm{mgAEg}^{-1}$ on a dry basis.

\subsection{Colour}

Colour instrumental parameters were quantified using a colorimeter (Color Quest, XE, HunterLab, Reston, USA). Grains were placed directly ont he colorimeter sensor $(35 \mathrm{~mm}$ of diameter) and measured by the Cielab Colour System. For each treatment, between 20 and 30 measurements were taken. The operations parameters were: viewing angle $10^{\circ}$ and illuminant D65 (corresponding to natural daylight).

\subsection{Proximate composition}

The moisture content (AOAC 925.45b) was determined in an oven at $105{ }^{\circ} \mathrm{C}$. Total nitrogen was quantified by the micro-Kjeldahl method $(\mathrm{N} \times 6.25)$ (AOAC 960.52) in a nitrogen distiller. Fat (AOAC 920.39) was separated in a Soxhlet apparatus with petroleum ether P.A. (Tecnal, TE-044, Piracicaba, Brazil). Ashes (AOAC 923.03) were determined by incineration in a muffle furnace (EDG, Oven Economic, São Carlos, Brazil), according to the methods recommended by the Association of Official Analytical Chemistry (2012). All analyses were performed in triplicate. Carbohydrates were determined by difference. All values were expressed in $\mathrm{g}^{100 \mathrm{~g}^{-1}}$, on a wet basis.

\subsection{Total amino acid profile}

The samples were ground, homogenized and digested to release amino acids from the proteins by hydrolysis, using hydrochloric acid for $22 \mathrm{~h}$ at $110^{\circ} \mathrm{C}$ under a vacuum in the digester block. Then, they were derivatized in a pre-column with phenyl isothiocyanate (PITC). Separation and identification of amino-feniltiocarbamil 
(PTC-aa) was performed in a high-performance liquid chromatography (Shimadzu Corporation, Tokyo, Japan) on a reversed column phase Phenomenex-Luna C18 (Phenimenex Inc., Torrence, CA, USA), $250 \mathrm{~mm} \times 4.6 \mathrm{~mm}$ and $5 \mu \mathrm{m}$. The mobile phase consisted of an acetate buffer solution, $\mathrm{pH}$ 6.4, and an acetonitrile solution of $40 \mathrm{~g} 100 \mathrm{~g}^{-1}$. Sample injection was performed automatically $(50 \mu \mathrm{L})$, and detection was at $254 \mathrm{~nm}$. Chromatographic separation was measured at a constant flow rate of $1 \mathrm{mLmin}^{-1}$ at $35^{\circ} \mathrm{C}$. The chromatographic run time was $45 \mathrm{in}$, and the results were expressed in $\mathrm{mg} 100 \mathrm{~g}^{-1}$. Identification of amino acids was performed by comparison to an external standard (Pierce, PN 20088). To quantify it, an internal standard of $\alpha$-aminobutyric acid was used (Sigma-Akdrich, St. Louis, MO, USA), according to Hagen et al. (1989).

\subsection{Trypsin inhibitor}

The quantification method for trypsin inhibitor activity was based on the hydrolysis of ester bond and amide of benzoyl-L-arginine p-nitroanilide (Bapa), by releasing a synthetic derivative of these amino acids through free trypsin action, which was not connected to the inhibitor present in the solution containing the sample (if trypsin inhibitor existed in the sample, it would inhibit the action of trypsin on the Bapa). During Bapa hydrolysis by trypsin, p-nitroanilide was released, which was measured in a spectrophotometer at $410 \mathrm{~nm}$ (Rackis et al., 1974).

\subsection{Microbiological risk}

The samples were evaluated according to the methods established by the American Public Health Association (2001). Coliforms at $45^{\circ} \mathrm{C}$, Staphylococci coagulase-positive, Salmonella sp., were evaluated after 10 days' incubation at $35-37^{\circ} \mathrm{C}$, and after 5 days of incubation at $55^{\circ} \mathrm{C}$, according to the RDC number 12 from January 2001, of the Brazillian Health Regulatory Agency - Anvisa (Brasil, 2001).

\subsection{Consumer acceptance and consumption intent}

To evaluate the acceptance of flavor, texture and appearance of the brown soybean preserve, a hedonic scale of nine points was used, with the extreme terms "like extremely" and "extremely disliked", and for consumption intent the scale was 5 points
( 1 = definitely not buy, 3 = maybe buy / may not buy and 5 = definitely buy) (Stone et al., 2012). An average grade of seven (7) was pre-established for consideration that the canned brown soybeans were accepted by the tasters. The panel was composed of 53 people with an age range of 20-40 years. (Number Ethic Committee 041/13).

\subsection{Analysis of results}

Data were evaluated by analysis of variance and multiple regressions, using Statistica 7.0 (Statsoft, Statistica 7.0, Tulsa, USA). The Response Desirability Profiling function was used to estimate the most desirable brown soybean preserve. The preserve with higher values of total phenolic compounds and chroma $\mathrm{a}^{*}$, and lower values of instrumental hardness and luminosity was considered the most desirable.

\section{Results and discussion}

\subsection{Physicochemical quality}

The hardness of the brown soybean preserves varied $157 \%$ (between 8.6 and $23.0 \mathrm{~N}$ ) (Table 1), which was influenced only by the linear $(\mathrm{p}<0.05)$ and quadratic effects of the maceration time $(\mathrm{p}<0.01)$ (Table 2$)$.

The increase in ascorbic acid did not influence hardness $(\mathrm{p}<0.05)$. The longer maceration time, less was the instrumental hardness (Figure 2). The reduction in the hardness of the grains is due to the water content absorbed by the leguminous grain in the maceration process, which causes less resistance to the grain (Pan \& Tangratanavalee, 2003). Brown soybeans (BRM line 04-4382-4), classified as large grains (15 mm diameter), which needed $50 \mathrm{~min}$ in the maceration process with cooking for $15 \mathrm{~min}$ at $121{ }^{\circ} \mathrm{C}$, showed hardness values (10.8 to $12.2 \mathrm{~N}$ ) similar to the those of the commercial preserve (Tables 1 and 3 ).

The antioxidant capacity of the brown soybean preserve ranged between 4.3 and 183.8 mgGAE100g $^{-1}$ (Table 1). The antioxidant capacity was significantly influenced by the linear effect $(\mathrm{p}<0.05)$ of the ascorbic acid concentration in the brine; however, the quadratic effects of the ascorbic acid and the maceration time were kept in the model to improve the fit (Table 2, Figure 2B). These results suggest that the maintenance of the antioxidant capacity

Table 1. Hardness $(\mathrm{N})$, antioxidant activity $\left(\mathrm{DPPH}^{\star}\right)\left(\mathrm{mg} \mathrm{GAE} 100 \mathrm{~g}^{-1}\right)$, total phenolic compounds (mg GAE $\left.100 \mathrm{~g}^{-1}\right)$, luminosity $\left(\mathrm{L}^{\star}\right)$, chroma

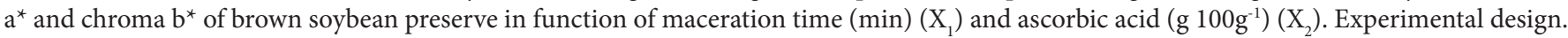

\begin{tabular}{cccccrrrrrr}
\hline Experiment & Maceration Time & Ascorbic Acid & Maceration Time & Ascorbic Acid & Hardness & DPPH $^{*}$ & Total Phenolic & $\mathrm{L}^{*}$ & $\mathrm{a}^{*}$ & $\mathrm{~b}^{*}$ \\
\hline 1 & -1 & -1 & 13.6 & 0.029 & 18.3 & 33.1 & 204.2 & 41.5 & 13.6 & 11.6 \\
2 & 1 & -1 & 85.4 & 0.029 & 8.6 & 33.2 & 204.4 & 43.2 & 13.6 & 12.5 \\
3 & -1 & 1 & 13.6 & 0.171 & 20.7 & 183.8 & 445.6 & 45.6 & 14.0 & 14.6 \\
4 & 1 & 1 & 85.4 & 0.171 & 12.2 & 143.5 & 445.0 & 47.4 & 12.0 & 12.4 \\
5 & -1.41 & 0 & 0 & 0.1 & 23.0 & 57.1 & 231.0 & 42.8 & 15.4 & 15.1 \\
6 & 1.41 & 0 & 100 & 0.1 & 9.4 & 72.6 & 351.0 & 46.2 & 14.5 & 15.4 \\
7 & 0 & -1.41 & 50 & 0.0 & 16.1 & 4.3 & 176.4 & 41.9 & 12.1 & 9.2 \\
8 & 0 & 1.41 & 50 & 0.2 & 10.8 & 114.6 & 466.2 & 46.0 & 14.8 & 15.6 \\
9 & 0 & 0 & 50 & 0.1 & 11.2 & 41.2 & 319.4 & 43.1 & 15.7 & 15.0 \\
10 & 0 & 0 & 50 & 0.1 & 11.8 & 32.7 & 318.3 & 45.0 & 15.7 & 14.3 \\
11 & 0 & 0 & 50 & 0.1 & 12.2 & 49.6 & 310.6 & 43.2 & 17.1 & 15.6 \\
\hline
\end{tabular}




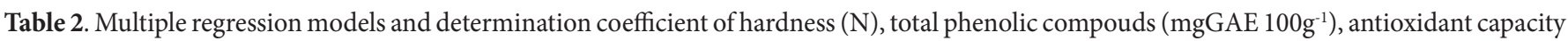
$\left(\mathrm{mgGAE} 100 \mathrm{~g}^{-1}\right)$, luminosity, chroma $\mathrm{a}^{\star}$ and chroma $\mathrm{b}^{*}$ from brown soybean preserve in function of the maceration time $\left(\mathrm{X}_{1}\right)$ and ascorbic acid concentration $\left(\mathrm{X}_{2}\right)$, in encoded values.

\begin{tabular}{ccc}
\hline Characteristic & Model & $\mathrm{R}^{2}$ \\
\hline Hardness & $\mathrm{y}=12.57^{*}-4.70 \mathrm{x}_{1}{ }^{*}+2.02 \mathrm{x}_{1}{ }^{2 * *}$ & 0.88 \\
Antioxidant capacity & $\mathrm{y}=41.01^{\star *}+21.07 \mathrm{x}_{1}{ }^{2 \mathrm{~ns}}+52.21 \mathrm{x}_{2}^{*}+18.37 \mathrm{x}_{2}{ }^{2 \mathrm{~ns}}$ & 0.85 \\
Total phenolic compounds & $\mathrm{y}=315.69^{*}+21.14 \mathrm{x}_{1}{ }^{\mathrm{ns}}+111.66 \mathrm{x}_{2}{ }^{*}$ & 0.95 \\
Luminosity & $\mathrm{y}=44.18^{*}+1.04 \mathrm{x}_{1}^{*}+1.77 \mathrm{x}_{2}{ }^{*}$ & 0.91 \\
Chroma a $^{*}$ & $\mathrm{y}=16.19^{*}-0.85 \mathrm{x}_{1}{ }^{2 \mathrm{~ns}}-1.60 \mathrm{x}_{2}{ }^{2 *}$ & 0.75 \\
Chroma b $^{*}$ & $\mathrm{y}=14.89^{*}+1.31 \mathrm{x}_{2}^{*}-1.71 \mathrm{x}_{2}{ }^{2 *}-0.78 \mathrm{x}_{1} \mathrm{x}_{2}{ }^{\mathrm{ns}}$ & 0.87 \\
\hline
\end{tabular}

${ }^{*} \mathrm{p}<0.01 ;{ }^{* *} 0.01 \leq \mathrm{p}<0,05 ;{ }^{\text {ns }} \mathrm{p}>0.10$, kept to improve the model fit.
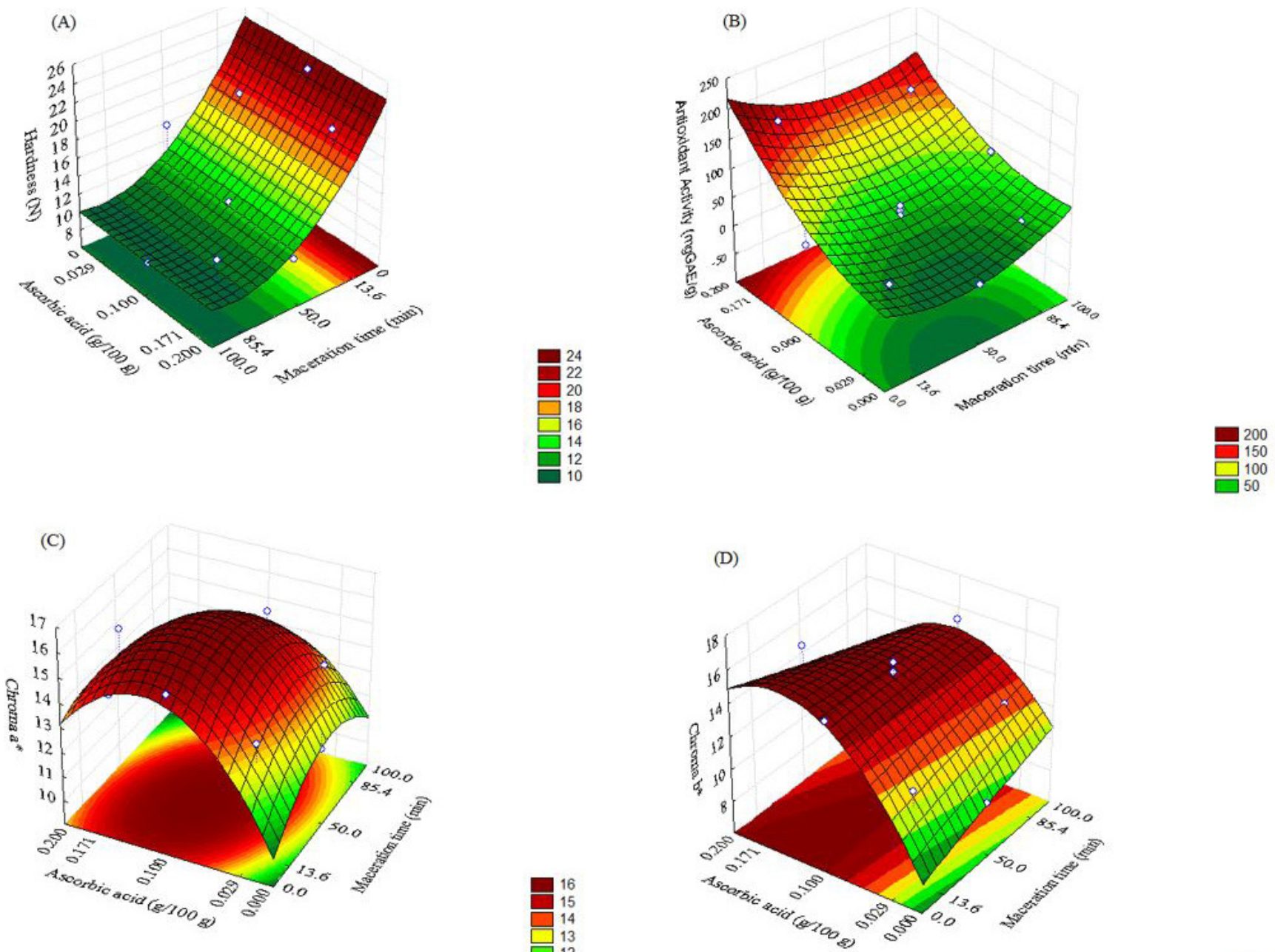

Figure 2. (A) Hardness, (B) Antioxidant activity, (C) Chroma a and (D) Chroma $b^{\star}$ from soybean grain (Glycinemax, BRM 04-4382-41 line),

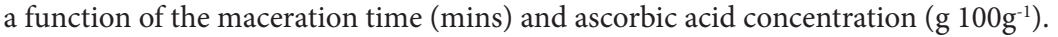

of the brown soybean (antioxidant capacity of the brown soybean in natura: $\left.200 \mathrm{mgGAE} 100 \mathrm{~g}^{-1}\right)$ is due to the presence of ascorbic acid. It acts in the regeneration of primary antioxidants, and slows down lipid oxidation, which increases the antioxidant capacity of the product (Sogvar et al., 2016). The antioxidant capacity of these compounds is attributed to the reducing power of the aromatic hydroxyl group, which reduces reactive free radicals, such as singlet oxygen, or decomposes peroxides to produce phenoxyl radical, a less reactive substance (Kim et al., 2015a).

The total phenolics of the brown soybean preserve ranged between 176.4 and $466.2 \mathrm{mgGAE} 100 \mathrm{~g}^{-1}$ (Table 1). These were also significantly influenced $(\mathrm{p}<0.01)$ by the linear effect of the ascorbic acid concentration in the brine. However, to improve the model fit, the linear effect of maceration time was 
maintained (Table 2). Brown soybean grain in natura presented $458.4 \mathrm{mgGAE} 100 \mathrm{~g}^{-1}$ of total phenolic compounds, which shows that in high concentrations, ascorbic acid contributes to the maintenance of these compounds in the preserve.

The maceration process contributes to the reduction of the antioxidant capacity of the grain and total phenolic compounds, since there is a loss of these compounds from leaching into the maceration solvent. This loss occurs because these are water-soluble compounds, which facilitates their extraction into the maceration water (Bayram et al., 2004a). In addition, heat treatment contributes to the increased loss of phenolic compounds by leaching of the phenolic hydrophilic compounds, degrading polyphenols, transforming phenolics and stimulating additional chemical reactions (Kim et al., 2015b). In particular, the loss of phenolic compounds significantly decreases when black soybeans are cooked rather than boiled, due to the amount of steam involved (Xu \& Chang, 2008).

The luminosity of the grains varied $14.21 \%$ (Table 1 ). The linear effects of the maceration time $(\mathrm{p}<0.05)$ and the ascorbic acid concentration $(\mathrm{p}<0.05)$ in the brine significantly influenced the luminosity of the brown soybean preserve (Table 2). Water absorption of the soybean grains increased with the maceration process time, as did the loss of pigments into the maceration water, contributing to the increase in the luminosity of the brown soybean preserve. In addition, temperature also contributes to increasing the luminosity of soybeans; it causes changes in their structure due to the penetration of water and the gelling of the compounds (protein, starch, etc.) in soybeans (Bayram et al., 2004b).

Chroma $\mathrm{a}^{*}$ of the grain varied $42.5 \%$ (Table 1 ), indicating a reddish hue in the soybean tegument. The quadratic effects of the maceration time $(\mathrm{p}<0.05)$ and the ascorbic acid concentration $(\mathrm{p}<0.05)$ in the brine influenced the color of the grain of the brown soybean preserve. From the response surface (Figure $2 \mathrm{C}$ ), it was found that the redder color (higher values of chroma $\mathrm{a}^{*}$ ) was obtained with intermediate concentrations of ascorbic acid and maceration time (maximum area); in other words, it was obtained in the center of the response surface plot.

Chroma $b^{\star}$ of the brown soybean preserve ranged between 9.2 and 15.6 (Table 1). The linear and quadratic effects of the ascorbic acid concentration in the brine of the brown soybean significantly influenced the chroma $b^{*}(p<0.05)$; however, the interaction effect between the concentration of ascorbic acid and the maceration time was maintained in order to improve the model fit (Table 2). The combination of a shorter maceration time and an increase in the concentration of ascorbic acid showed higher chroma $b^{*}$ values (Figura $1 D$ ), resulting in soybean grains in preserve with a more yellowish colour. In maceration, longer times predominated the quadratic effect; in other words, the highest values of chroma $b^{*}$ were observed at intermediate concentrations of ascorbic acid.

The increase in the reddish hue is due to the degradation of chlorophyll. The increase in the yellowish hue occurs due to the degradation effect of the temperature on the chemical structure of carotenoids. Broken carotenoid structures turn a reddish hue to a slightly yellowish one (short chemical structure) (Bayram et al., 2004b).

In the desirability test, a brown soybean preserve with lower hardness, a higher percentage of phenolic compounds and antioxidant activity, and more intense colors (more reddish and yellowish) was selected, and these characteristics were obtained with a maceration time of $23 \mathrm{~min}$ and 49s (- 0.705)

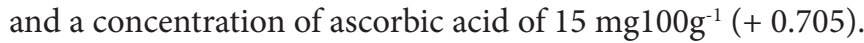
The maceration time and ascorbic acid content used in order to obtain the brown soybean with greater desirability were also used to produce the preserve and model validation test.

The hardness of the brown soybean preserve obtained during the validation test was $15.6 \mathrm{~N}$, approximately $8.2 \%$ lower than expected by the model $(17 \mathrm{~N})$, so acceptable, and $34.5 \%$ higher than the hardness value of the commercial yellow soybean preserve. The difference between the estimated value and the model value for the antioxidant activity was low (3.1\%). Antioxidant activity in the brown soybean grains in natura was 9.1 times higher than the selected soybean preserve. For the concentration of total phenolics, the model also showed little difference $(2.5 \%)$ between expected and obtained results, showing a loss of $24.0 \%$ of the total phenolic compounds present in the grain in natura (Table 3 ).

Study on bean preserves subjected to autoclaving found a loss in total phenolic compounds (90\%) (Pedrosa et al., 2015). This loss was higher than the one verified in this study, probably due to the incorporation of ascorbic acid into the brown soybean preserve. Studies have demonstrated that the phenolic composition of dark grains is related to the binomial time-temperature employed during the cooking process, which directly reflects on their neuroprotective and anti-carcinogenic activity. The cooking of

Table 3. Expected and measured values for hardness $(\mathrm{N})$, antioxidant capacity $\left(\operatorname{mgGAE} 100 \mathrm{~g}^{-1}\right)$, total phenolic compounds (mg GAE $\left.100 \mathrm{~g}^{-1}\right)$, luminosity, chroma $\mathrm{a}^{*}$ and chroma $\mathrm{b}^{*}$ of brown soybean preserve (Glycine max, BRM 04-4382-41 line), and hardness of commercial yellow soybeans preserve. Amounts in average followed by standard deviations.

\begin{tabular}{|c|c|c|c|c|}
\hline Characteristic & Grain in natura & Preservecommercial $^{2}$ & Expected values & Measured values \\
\hline Hardness & $\mathrm{ND}^{1}$ & $11.6 \pm 1.5$ & 17.0 & $15.6 \pm 0.9$ \\
\hline Antioxidant capacity & $210.9 \pm 9.2$ & ND & 198.0 & $191.8 \pm 7.6$ \\
\hline Total phenolic & $487.14 \pm 18.2$ & ND & 380.0 & $370.4 \pm 12.3$ \\
\hline Luminosity & $44.0 \pm 1.71$ & ND & 45.0 & $45.4 \pm 3.64$ \\
\hline Chroma a $^{*}$ & $9.08 \pm 1.29$ & ND & 15.0 & $17.1 \pm 1.02$ \\
\hline Chroma b* $^{*}$ & $3.43 \pm 1.52$ & ND & 15.0 & $12.8 \pm 1.22$ \\
\hline
\end{tabular}

${ }^{1} \mathrm{ND}$ (not determined); ${ }^{2}$ Yellow soybeans commercial preserve. 
dark grains also improves their digestion and absorption at the intestinal level, maintaining protective capacity in the oxidative process at the cellular level (López et al., 2013).

The luminosity of the soybean grains in preserve obtained in the validation models was $0.9 \%$ higher than the value estimated by the model and 3.2\% higher than the grain in natura (Table 3 ). The chroma $\mathrm{a}^{*}$ obtained in the test was $14.0 \%$ higher than estimated by the model and $88.3 \%$ higher than the grain in natura. The value of chroma $b^{*}$ was $14.7 \%$ higher than estimated by the model and 3.7 times higher than the grains in natura. Therefore, the models for hardness, antioxidant activity, TPC, and luminosity can be considered predictive, due to the presented acceptable variations (below 10\%). The results of this test on the selected preserve, compared with the values obtained from the grain in natura, indicate that processing has increased lightness; in other words, it has decreased the dark color of the brown soybean and also promoted an increase in reddish and yellowish hues in the grains of the soybean preserve.

\subsection{Chemical composition of selected brown soybean preserve}

The brown soybean preserve presented a moisture content six times higher than the grains in natura (Table 4). The high moisture content of the preserve is due to the stages of the maceration process and cooking, during which the grains absorb water. Silva et al. (2013) evaluated the proximal composition of raw and cooked beans and found the moisture value of the cooked grain to be 5 times higher than the grain in natura (raw); these values were below those of the brown soybean preserve.

Considerable ash wins were observed in the soybean preserve in relation to the grain in natura (Table 4), in dry basis. On the other hand, studies reported the loss of minerals during the processing of peas and beans. This decrease in ash content is related to the leaching of minerals into the maceration water and/or the cooking water of these grains studies (Wang et al., 2010; Pedrosa et al., 2015).

No losses in lipid, protein and carbohydrate contents during the processing of the brown soybean preserve were observed, if considere the dry bassis (Table 4). Moreover, when comparing this result with the commercial yellow soybean, it was found that the lipid content was similar, while the protein and carbohydrate contents of the brown soybean preserve were higher than the commercial yellow soybean preserve (26.6 and $21.6 \%$, respectively), showing the higher quality of the product. Wang et al. (2010) observed that increases in the concentrations of carbohydrates and proteins in beans and chickpeas were due to the loss of soluble solids in the cooking water, which would increase the concentration of these constituents in the cooked product. Andalso report that the type of processing influences the proximal composition of the cooked product.

The processing of the brown soybean preserve increased the protein quality of the grain because the amino acid content of the preserve was higher than the values obtained from the grains in natura, especially concerning cysteine (conditionally essential), with $90.6 \%$ growth, and methyl-cysteine, with an increase of 59.9\% (essential) (Table 5).

Heat treatments for food, such as immersion, boiling, cooking in a microwave and autoclaving, increase the total essential amino acids in leguminous grains. In particular, autoclaving increases significantly the total essential amino acids when compared to other processing methods (Khattab et al., 2009). Increases in amino acid content after heat treatment is the result of protein degradation. This finding is consistent with the results of the present study, in which the total content of essential amino acids increased in the brown soybean preserve after cooking with the application of heat (Table 5). A similar result was observed in soybeans cooked with rice (Kim et al., 2015b).

It has been found that higher concentrations of amino acids in the grains in natura and in preserve were from glutamic acid, aspartic acid, arginine and phenylamine+tyrosine (Table 5). Higher values of essential amino acids, which need to be provided by the diet, were found for phenylamine+tyrosine, and lower values for methionine+cysteine, for grains in natura and in preserve. Higher values of conditionally essential amino acids, in other words, those that become essential under certain pathological conditions or organism development, were found for arginine and proline, where the highest values were obtained for the soybean preserve. The brown soybean preserve showed higher values for all essential amino acids, when compared to the standard value suggested for healthy children and adults by the Food and Nutrition Board (2005). In short, the amino acid composition of the brown soybean preserve met the amino acids standard proposed for ageshigher than orequal to one year, as recommended by the Food and Nutrition Board.

Trypsin inhibitor was present in the brown soybean grains in natura (15.734.18UI g-1 \pm 5.6 ), but it was not found in the brown soybean preserve (zero); in other words, the processing of the preserve inactivated the trypsin inhibitor. In a study on the effect of some physical treatments on the nutritional quality of beans and peas, Khattab \& Arntfield (2009) reported that

Table 4. Moisture, ashes, protein, lipids and carbohydrates ofthe in natura grain and selected brown soybean preserve (Glycine max, BRM 04-4382-41 line). Average followed by standard deviation and variation coefficient.

\begin{tabular}{cccc}
\hline Parameter & in natura grain & Preserve grain & Commercial yellow preserve $^{2}$ \\
\hline Moisture $^{1}$ & $10.14 \pm 0.04(0.43)$ & $64.87 \pm 1.02(1.58)$ & - \\
Ashes $^{1}$ & $6.44 \pm 0.23(3.61)$ & $4.28 \pm 0.19(4.43)$ & 5.9 \\
Lipids $^{1}$ & $15.20 \pm 0.11(0.74)$ & $5.97 \pm 0.20(3.27)$ & 6.0 \\
Protein $^{1}$ & $34.66 \pm 0.75(2.17)$ & $13.93 \pm 0.04(0.26)$ & 11 \\
Carbohydrates $^{1}$ & 33.56 & 10.95 & 9 \\
\hline
\end{tabular}

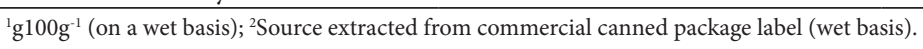


Table 5. Essential, conditionally essential, non-essential and total amino acids of brown soybean fresh and pickled in $\mathrm{mg}$ amino acid/g protein and the proposed pattern of amino acids for infants, preschool children and adults based on estimated needs for protein and essential amino acids.

\begin{tabular}{|c|c|c|c|c|c|c|}
\hline \multirow{2}{*}{$\begin{array}{c}\text { Essential } \\
\text { Amino acids }\end{array}$} & \multirow{2}{*}{$\begin{array}{c}\text { Grain } \\
\text { in natura }\end{array}$} & \multirow{2}{*}{$\begin{array}{c}\text { Preserve } \\
\text { grain }\end{array}$} & \multirow{2}{*}{ Range \% } & \multicolumn{3}{|c|}{ Standard $^{1}$} \\
\hline & & & & Infants $^{\mathrm{a}}$ & 1 to 3 years $^{\mathrm{b}}$ & $\geq 18$ years $^{\mathrm{b}}$ \\
\hline Leucine & 71.32 & 78.79 & 10.5 & 101 & 55 & 52 \\
\hline Lysine & 60.97 & 64.27 & 5.4 & 69 & 51 & 47 \\
\hline Fenil + tirosina & 80.14 & 89.56 & 11.8 & 87 & 47 & 41 \\
\hline Valine & 45.59 & 51.79 & 13.6 & 56 & 32 & 29 \\
\hline Isoleucine & 41.96 & 46.82 & 11.6 & 57 & 25 & 23 \\
\hline Threonine & 40.42 & 44.13 & 9.2 & 47 & 27 & 24 \\
\hline Metio+Cisteína & 26.42 & 42.25 & 59.9 & 38 & 25 & 23 \\
\hline \multicolumn{7}{|c|}{ Conditionally essential amino acids } \\
\hline Tyrosine & 33.57 & 35.13 & 4.6 & - & - & - \\
\hline Cysteine & 13.87 & 26.44 & 90.6 & - & - & - \\
\hline Arginine & 79.48 & 89.74 & 12.9 & - & - & - \\
\hline Glycine & 40.27 & 44.06 & 9.4 & - & - & - \\
\hline Proline & 45.9 & 51.8 & 12.9 & - & - & - \\
\hline \multicolumn{7}{|c|}{ Non-essential amino acids } \\
\hline Glutamic acid & 184.85 & 202.09 & 9.3 & - & - & - \\
\hline Aspartic acid & 116.57 & 124.58 & 6.9 & - & - & - \\
\hline Serina & 50.06 & 55.88 & 11.6 & - & - & - \\
\hline Alanine & 41.49 & 44.00 & 6.0 & - & - & - \\
\hline $\mathrm{TAA}^{\mathrm{c}}$ & 972.88 & 1091.33 & 12.2 & - & - & - \\
\hline TEAA $^{\mathrm{d}}$ & 366.82 & 417.61 & 13.8 & 455.00 & 262.00 & 239.00 \\
\hline TCEAA $^{\mathrm{e}}$ & 213.09 & 247.17 & 16.0 & - & - & - \\
\hline TNEAA $^{\mathrm{f}}$ & 392.97 & 426.55 & 8.5 & - & - & - \\
\hline
\end{tabular}

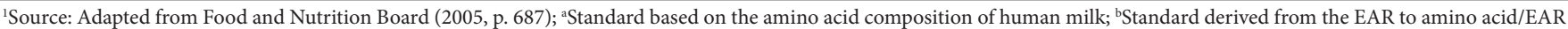
for protein; for group of 1 to 3 years protein $\mathrm{EAR}=0.88 \mathrm{~g} / \mathrm{kg}$ day and for adults protein $\mathrm{EAR}=0.66 \mathrm{~g} / \mathrm{kg}$ day. EAR is the estimated average requirement; ${ }^{\mathrm{T}} \mathrm{TAA}=$ total amino acid; ${ }^{\mathrm{d}} \mathrm{TEAA}=$ total essential amino acids; ${ }^{\mathrm{e}} \mathrm{TCEAA}=$ total conditionally essential amino acids; and ${ }^{\mathrm{f}} \mathrm{TNEAA}=$ total non-essential amino acids.

the maceration process and heat treatment participate in the reduction and inactivation of the trypsin inhibitor, respectively. Inactivation of trypsin inhibitors by heat treatment, due to protein denaturation, depends on the applied temperature and grain exposure time (Wang et al., 2010).

\subsection{Microbiological risk and sensory evaluation}

The microbiological counts of the brown soybean preserve were below the maximum limits established by Brazilian law: Thermotolerant Coliforms $\left(10^{2} \mathrm{CFU} \mathrm{g}^{-1}\right)$, Staphylococci coagulase

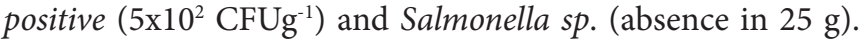
Furthermore, the brown soybean preserve, after 10 days of incubation at $35-37^{\circ} \mathrm{C}$ and after 5 days of incubation at $55^{\circ} \mathrm{C}$, did not change the results obtained for the three evaluated microorganisms. The results suggest that the brown soybean preserve that was produced was a microbiologically safe product, reinforcing the hypothesis that raw materials and proper handling methods were used. The average scores and standard deviations obtained for the selected brown soybean preserve were $7.1 \pm 1.5$ for appearance, $7.2 \pm 1.6$ for texture and $7.1 \pm 1.7$ for flavor. All averages were between moderately liked and enjoyed. Therefore, the scores were above the preset limit for acceptance of the preserve, which was greater than or equal to six. Scores for purchase intent ranged between 3 (maybe buy / may not buy) and 4 (possibly buy). The tasters also reported a lack of soybean preserve consumption, which might have negatively affected the results.

\section{Conclusions}

The hardness of the grains in preserve is not affected by the addition of ascorbic acid, but only by the maceration time, reaching the same texture as the commercial soybean. Antioxidant activity and total phenolic compounds are preserved by the addition of ascorbic acid. The best brown soybean preserve is obtained with a maceration time of $23 \mathrm{~min}$ and an ascorbic acid concentration of $0.15 \mathrm{~g} 100 \mathrm{~g}^{-1}$. The brown soybean preserve shows a high nutritional value, higher than the commercial yellow soybean preserve, amino acid contents above the standards recommend for ages higher than or equal to one year, absence of trypsin inhibitor and microbiological risk, as well as sensory acceptance. Therefore, the brown soybean preserve is viable, and its production and consumption are recommended.

\section{Acknowledgements}

The authors thank the Coordination for the Improvement of Higher Education Personnel (CAPES) for their financial support.

\section{References}

American Public Health Association - APHA. (2001). Compendium of methods for the microbiological examination of foods (4th ed.). Washington: APHA.

Association of Official Analytical Chemistry - AOAC. (2012). Official methods of analysis (19th ed.). Gaithersburg: AOAC. 
Bayram, M., Kaya, A., \& Oner, M. D. (2004a). Changes in properties of soaking water during production of soy-bulgur. Journal of Food Engineering, 61(2), 221-230. http://dx.doi.org/10.1016/S02608774(03)00094-3.

Bayram, M., Oner, M. D., \& Kaya, A. (2004b). Influence of soaking on the dimensions and colour of soybean for bulgur production. Journal of Food Engineering, 61(3), 331-339. http://dx.doi.org/10.1016/ S0260-8774(03)00137-7.

Box, G. E. P., Hunter, W. G., \& Hunter, J. S. (2005). Statistics for experimenters: design, innovation, and discovery (2nd ed.). New York: John Wiley.

Brasil, Agência Nacional de Vigilância Sanitária - ANVISA. (2001, January 10). Aprova o regulamento técnico sobre padrões microbiológicos para alimentos (Resolução de Diretoria Colegiada - RDC n 12, de 2 de janeiro de 2001). Diário Oficial [da] República Federativa do Brasil. Retrieved from http://portal.anvisa.gov.br/legislacao\#/ visualizar/26655

Ciabotti, S., Silva, A. C. B. B., Juhasz, A. C. P., Mendonça, C. D., Tavano, O. L., Mandarino, J. M. G., \& Gonçalves, C. A. A. (2016). Chemical composition, protein profile, and isoflavones content in soybean genotypes with diferente seed coat colors. International Food Research Journal, 23(2), 621-629.

Food and Nutrition Board - FNB. (2005). Dietary References Intakes for energy, carbohydrate, fiber, fat, fattyacids, cholesterol, protein, and amino acids: macronutrients. Washington: The National Academies Press. Retrieved from http://www.nap.edu/openbook. php?isbn=0309085373

Hagen, S. R., Frost, B., \& Augustin, J. (1989). Precolumn phenyl isothiocyanate derivatization and liquid chromatography of amino acids in food. Journal - Association of Official Analytical Chemists, 72(6), 912-916. PMid:2592313.

Hung, P. V., Maeda, T., Miyatake, K., \& Morita, N. (2009). Total phenolic compounds and antioxidant capacity of wheat graded flours by polishing method. Food Research International, 42(1), 185-190. http://dx.doi.org/10.1016/j.foodres.2008.10.005.

Khattab, R. Y., \& Arntfield, S. D. (2009). Nutritional quality of legume seeds as affected by some physical treatments 2 : antinutritional factors. Lebensmittel-Wissenschaft + Technologie, 42(6), 1113-1118. http://dx.doi.org/10.1016/j.lwt.2009.02.004.

Khattab, R. Y., Arntfield, S. D., \& Nyachoti, C. M. (2009). Nutritional quality of legume seeds as affected by some physical treatments, part 1: protein quality evaluation. Lebensmittel-Wissenschaft + Technologie, 42(6), 1107-1112. http://dx.doi.org/10.1016/j.lwt.2009.02.008.

Kim, E. H., Lee, O. K., Kim, J. K., Kim, S. L., Lee, J., Kim, S. H., \& Chung, I. M. (2014). Isoflavones and anthocyanins analysis in soybean (Glycine max (L.) Merill) from three different planting locations in Korea. Field Crops Research, 156, 76-83. http://dx.doi. org/10.1016/j.fcr.2013.10.020.

Kim, J. Y., Kim, M. J., Yi, B., Oh, S., \& Lee, J. H. (2015a). Antioxidant properties of ascorbic acid in bulk oil sat different relative humidity. Food Chemistry, 176, 302-307. http://dx.doi.org/10.1016/j. foodchem.2014.12.079. PMid:25624237.

Kim, S. H., Yu, B. R., \& Chung, I. M. (2015b). Changes in the contents and profiles of selected phenolics, soyas apogenols, tocopherols, and amino acids during soybean-rice mixture cooking: electric rice cooker select ric pressure rice cooker. Food Chemistry, 176, 45-53. http://dx.doi.org/10.1016/j.foodchem.2014.12.024. PMid:25624205.

López, A., El-Naggar, T., Dueñas, M., Ortega, T., Estrella, I., Hernández, T., Gómez-Serranillos, M. P., Palomino, O. M., \& Carretero, M. E. (2013). Effecting cooking and germination on phenolic composition and biological properties of dark beans (Phaseolus vulgaris L.). Food Chemistry, 138(1), 547-555. http://dx.doi.org/10.1016/j. foodchem.2012.10.107. PMid:23265523.

Mozzoni, L. A., Morawicki, R. O., \& Chen, P. (2009). Canning of vegetable soybean: procedures and quality evaluations. International Journal of Food Science \& Technology, 44(6), 1125-1130. http://dx.doi. org/10.1111/j.1365-2621.2009.01929.x.

Pan, Z., \& Tangratanavalee, W. (2003). Characteristics of soybeans as affected by soaking conditions. Lebensmittel-Wissenschaft + Technologie, 36(1), 143-151. http://dx.doi.org/10.1016/S0023-6438(02)00202-5.

Pedrosa, M. M., Cuadrado, C., Burbano, C., Muzquiz, M., Cabellos, B., Olmedilla-Alonso, B., \& Asensio-Vegas, C. (2015). Effects of industrial canning on the proximate composition, bioactive compounds contents and nutritional profile oftwo Spanish common drybeans (Phaseolus vulgaris L.). Food Chemistry, 166, 68-75. http://dx.doi. org/10.1016/j.foodchem.2014.05.158. PMid:25053030.

Rackis, J. J., Mc Ghee, J. E., Kakade, M. L., \& Puski, G. (1974). Problems encountered inmeasuring trypsin inhibitor activity of soy flour. Report of a Collaborative Analysis Cereal Science Today, 19(11), 513-515.

Silva, M. O., Brigide, P., \& Canniatti-Brazaca, S. G. (2013). Composition of common bean cultivars. Brazilian Journal Food Nutrition, 24(1), 339-346.

Singleton, V. L., Orthofer, R., \& Lamuela-Raventos, R. M. (1999). Analysis of total phenols and others oxidation substrates and antioxidants by means of Folin-Ciocaulteau reagent. Methods in Enzymology, 299(1), 152-178. http://dx.doi.org/10.1016/S0076-6879(99)99017-1.

Sogvar, O. B., Koushesh Saba, M., \& Emamifar, A. (2016). Aloe vera and ascorbic acid coatings maintain postharvest quality and reduce microbial load of strawberry fruit. Postharvest Biology and Technology, 114(2), 29-35. http://dx.doi.org/10.1016/j.postharvbio.2015.11.019.

Stone, H., Bleibaum, R., \& Thormas, H. (2012). Sensory evaluation practices (4th ed.). New York: Academic Press.

Thaipong, K., Boonprakob, U., Crosby, K., Cisneros-Zevallos, L., \& Hawkins Byrne, D. (2006). Comparison of ABTS, DPPH, FRAP, and ORAC assays for estimating antioxidant activity from guava fruit extracts. Journal of Food Composition and Analysis, 19(6-7), 669-675. http://dx.doi.org/10.1016/j.jfca.2006.01.003.

Wang, N., Hatcher, D. W., Tyler, R. T., Toews, R., \& Gawalko, E. J. (2010). Effect of cooking on the composition of beans (Phaseolus vulgaris L.) and chickpeas (Cicerarietinum L.). Food Research International, 43(2), 589-594. http://dx.doi.org/10.1016/j.foodres.2009.07.012.

Xu, B., \& Chang, S. K. C. (2008). Total phenolics, phenolic acids, isoflavones, and anthocyanins and antioxidant properties of yellow and black soybeans as affected by the rmalprocessing. Journal of Agricultural and Food Chemistry, 56(16), 7165-7175. http://dx.doi. org/10.1021/jf8012234. PMid:18680298. 